rev.relac.int.estrateg.segur.10(2):111-129,2015

\title{
THE RELATION BETWEEN THE FOREIGN DIRECT INVESTMENTS AND THE ECONOMIC SECURITY IN LATIN AMERICA*
}

\author{
Cosmin Gabriel Bolea**
}

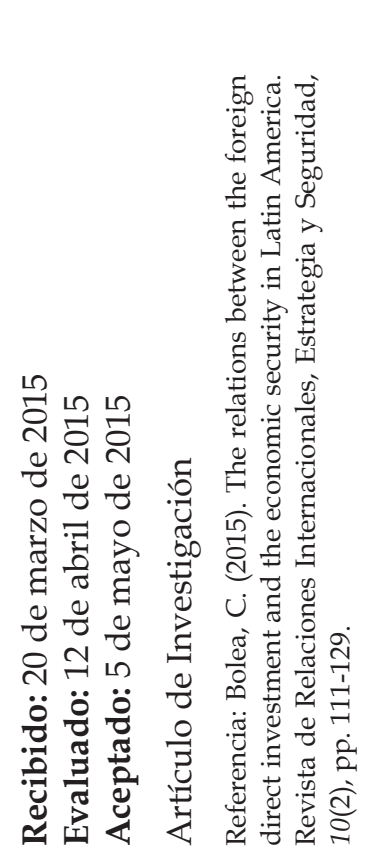

\section{ABSTRACT}

The main objective of the article is to analyse the economic security understood as macroeconomic stability through the following variables: the ratio of foreign direct investment in Latin America with the value of the corruption index, the GINI coefficient and the Gross Domestic Product. The hypothesis is that the higher the GINI coefficient is and lower is the score in the ranking of corruption index according to Transparency International, the country receives greater investment and greater is his level of economic security, even if is not the only condition. We demonstrate empirically, trough econometric analyses, that there is a strong correlation between the mentioned variables in the case of Latin America countries, emphasis on extreme cases of Uruguay and Venezuela and the more moderate

This research was developed with the support of "Fellow Program Postdoctoral Fellowships 2014" at Economic Research Institute, UNAM, Mexico City.

** Posdoctoral studies in Economy, National Autonomus University of Mexico. UNAM. E-mail: cos1984sel@yahoo.es. 
of Mexico and Brazil. As far as we know there is no study for Latin American countries, regarding economic security issues, using this methodology, where finally the hypothesis for all the mentioned countries is confirmed.

Keywords: Latin America, GINI coefficient, Corruption, Foreign Direct Investment, Economic Security.

\section{LA RELACIÓN ENTRE LA INVERSIÓN EXTRANJERA DIRECTA Y LA SEGURIDAD ECONÓMICA. CASOS EN AMÉRICA LATINA}

\section{RESUMEN}

El objetivo principal del artículo es analizar la seguridad económica, entendida como estabilidad macroeconómica a través de las siguientes variables: la relación de los flujos de inversión extranjera directa en América Latina con el valor del índice de corrupción, el coeficiente GINI y el Producto Interior Bruto. La hipótesis parte del hecho de que cuanto mayor sea el coeficiente GINI y menor la puntuación en el ranking de corrupción según Transparency International, mayor inversión recibe el país y mayor es su nivel de seguridad económica aunque no es la única razón. Hemos demostrado empíricamente mediante un análisis econométrico que hay una fuerte correlación entre las variables mencionadas en caso de los países de América Latina, haciendo hincapié en los casos extremos de Uruguay y el de Venezuela y los más moderados de México y Brasil. Por lo que tenemos conocimiento no hay ningún estudio relacionado a la seguridad económica usando esta metodología para el caso de América Latina, donde al final se confirma la hipótesis planteada.

Palabras clave: América Latina, Coeficiente GINI, Corrupción, Inversión Extranjera Directa, Seguridad Económica.

\section{A RELAÇÃO ENTRE O INVESTIMENTO ESTRANGEIRO E A SEGURANÇA ECONÔMICA NA AMÉRICA LATINA}

\section{RESUMO}

O objetivo principal do artigo é analisar a segurança econômica entendida como a estabilidade macroeconômica através das seguintes variáveis: a relação do investimento estrangeiro na América Latina com o valor do índice de corrupção, o coeficiente de GINI e do Produto Interno Bruto. A hipótese diz que quanto maior valor tem o coeficiente de GINI e quanto menor é a pontuação no ranking de corrupção de acordo com a Transparency International, o país recebe mais investimentos e maior é seu nível de segurança econômica, mais isso não é a única razão. Demonstramo-nos empiricamente através de um análise econométrico que entre as variáveis 
apresentadas tem uma forte correlação em caso dos países da América Latina, com ênfase nos casos extremos, do Uruguai e da Venezuela e dos mais moderados do México e O Brasil. Até onde nos temos conhecimento não tem outro artigo relacionado a segurança econômica usando esta metodologia onde nos finalmente confirmamos a hipótese apresentada.

Palavras-chave: América Latina, Coeficiente GINI, Corrupção, Inversão Estrangeira, Segurança Econômica.

\section{INTRODUCTION}

The economic theory says that in order to grow, a country need to have accumulated a necessary and sufficient savings in order to productive investment. All countries in Latin America need internal and foreign capital accumulation but in any case they need investments. When a country itself is not able to generate domestic savings, it is necessary to be attractive enough to convince foreign savers to invest in the country. This is achieved by offering a modernization and legal security of the Foreign Direct Investment (onward as FDI) and offering an openness of the commercial trade. Many studies pointed that the FDI is an essential part of the process of registered international economic globalization in recent decades. In fact, global flows of FDI have increased almost continuously since the seventies. However, the most spectacular growth occurred in the second half of the nineties, peaking in terms of GDP, in 2000 with an amount equivalent to $4.4 \%$ of world GDP.

The issue of the FDI is a much argued one and could be seen as the economic need of foreign capital but as well as an experience of 'good practices' from other countries. The State as the major authority is the one who "make the rules of the economy and look after his fulfilment" but if the State is not able to do it, mainly because of a weak state of law and high corruption could lead to political and social turmoil that keep away the investors or the benefits of the FDI are quite uneven among the economic sectors and the income distribution of the worker population. The national security we understand it, in this case as a macroeconomic stability, but once this last one is affected could treat the economic security and therefore trough political and social channel could lead in some cases to a national security problem. Unfortunately this is the case of almost all Latin American countries, but in this study we present the cases of: Brazil, Mexico, Chile, Colombia, Argentina, Panama, Peru, Uruguay, Venezuela and Costa Rica.

In this paper we highlight the relation between the FDI flows, in the first ten Latin American economies with the corruption index, the GINI coefficient in the context of the economic security using official CEPALSTAT figures and Transparency International corruption index. The results show that there is a strong correlation between the variables using econometrics analysis and finally we will see how the hypothesis is confirmed. The paper proceeds as follows: first we provide a brief literature review and some theoretical aspects of the FDI and economic security; the next section tackles the descriptive statistics on FDI in the first ten 
economies of Latin America and the relation with the corruption index and GINI coefficient. The final section we reinforce our hypothesis with some econometric finds. Finally we present the main conclusions.

\section{LITERATURE REVIEW}

Related to the concept of FDI are two theoretical elements that are relevant, the first concerning who is carrying out this investment, and therefore the study of internal corporate characteristics, its method of administration, organizational structure, or decision-making, aspects that are out of this analysis. The second element relates to the explanations on the movement and location of the capital at international and regional level, a key in order to understand the trends and causes of FDI flows.

This theoretical qualification becomes important because, even if we focus on the theories of FDI location it is very important at the same time to study the treatment of the role of the company, which is associated with the external characteristics such as market structure, competitive environment, stability and predictability of the economy. That is why the study on FDI boost at present is intrinsically related to the study of how each company adapted to the economic contexts, where it was located and why, issues that have been explained from different perspectives. These theoretical approaches have been varied, so for practical purposes in this analysis, we highlight the two main groups: the classic approach and the modern approach.

The classical models of Heckscher-Ohlin $(1933)$ or Ricardo $(1817,1996)$ are studying changing trade patterns to economic integration. In his opinion, each country will specialize in the production of products which possess a higher relative productivity or high relative endowment of factors used intensively, which explain the motion of FDI. These theoretical proposals, based on the comparative advantage of countries is quite unrealistic at present days despite the contributions such as Kojima (1976) who gives a more current role of the FDI in businesses. The previous theory has evolved and the role of business in commercial interaction starts to become relevant, first trade expands markets, frontier production and exports, so it will increase the surplus output (idle resources in the absence of trade), influencing factors and the movement of investment across sectors or countries, or exploiting those resources more abundantly in an economy (availability of scarce resources).

On the other hand the degree of innovation and imitation between firms in different countries will also determine the level of trade and investment (gap imitation of new products by innovating country), which affects the product cycle, satisfied the demand of the domestic market, a change in the domestic and foreign demand is observed, the company will make more investments in order to meet different markets (new product, and standardized product mature product). These are the contributions of Myint (1958), Kravis (1956) and Posner (1961). With a macroeconomic court will reach a more realistic analysis widespread today, focusing on the role and characteristics of the company and the markets in which it interacts, highlighting 
the role of the economies of scale associated with the location and imperfect markets, known as the New International Trade Theory, Krugman and Obstfeld (1995) where they analyzed models in which firms operate under imperfect competition and increased profits resulting from the decrease of barriers.

Among the theories of growth models they have focused on the effect of discussing savings and investment (Harrod,1939; Domar, 1946), but we don't have to forget the neoclassical models that emphasize technological progress (Solow, 1957), and endogenous growth models who emphasize the importance of human capital, research and development and external economies.

It was found that in export-oriented developing countries, FDI has a significant impact on the human capital endowment to increase the transfer of job skills. (Balasubramanyan et al., 1996). From the theoretical point of view it is considered that FDI are a direct source in generating human capital and technology by allowing generating externalities and spillovers. In the conditions of higher human capital lead to a high 'value added' in a company activity and therefore more jobs are created and usually higher are the incomes of the employees. Talking about the FDI, it is important to consider the income and how could this be redistributed in the economy and in which extent could generate economic and social welfare as Cruz (2015) explains in his investigation using the case of the European Union.

Regarding contemporary approaches, much of the current literature can be grouped into three areas:

- The approach focused on the international marketing associated with the country brand and competitive advantage, which raises the importance of concentration and diversification of markets and marketing efforts, business factors, market and product association. The investment is seen here as a basis for product differentiation and increased profitability for monopolistic profits, Kotler et al. (1998), Shoham (1999), among others.

- The economic dimension, highlights the role of: outward FDI, policies promoting internationalization, localization strategies and the role of SMEs, giving greater importance to the role of the location of FDI , the geographical, sectorial and market analysis of the natural resource, to the investment derived from competition in local markets, to increasing returns associated with economies of scale and to location and competitive advantages, treated by authors such as Caves (1982), Dunning (1988), or Porter (1991).

- Finally, the organizational approach is based on models for managing multinational companies. These views basically reflect the dichotomy of investment flows between source and destination, which respond to the factors and reasons why companies invest only in certain places (inputs and outputs of FDI). Here we are dealing with analytical elements such as the international strategic competence, financial and strategic planning, 
the importance of strategic management, leadership and networks, intangible assets and cultural advantages as triggers to investment raised by authors like Porter (1991) or Johanson \& Vahlne (1977).

These approaches provide the most common frameworks to address the determinants of FDI, different terms and ways to approach the reason for existence and relevance of the investment. Traditional approaches based on comparative advantage and therefore the analysis of comparative costs have proven inadequate and limiting to explain nowadays reality for several reasons, including imperfect mobility factors or government intervention in the specialization (Eiteman, Stonehill \& Moffet, 2007).

The contemporary approaches try to overcome these limitations by considering elements of imperfect markets, information asymmetry problems and costs and the role of economies of scale, however each stream skews his analysis to some extent, marketing, economics or organization, which has lacked comprehensive or consistent framework for analyzing the determinants of the FDI. The most common way to study the FDI alternative is given by Dunning, the eclectic paradigm also called "OLI paradigm", which offers a general framework to explain why companies choose FDI rather than other alternatives such as licensing or strategic alliances.

This proposal suggests that the motion of FDI is not an isolated fact or interpretable from a single perspective, but there is an active agent - the TNC, whose activities determine the investment movement, in that sense, the internationalization of the company is derived the existence of three types of benefits, also called in the economics competitive advantages:

- Advantages of Ownership - Ownership-specific advantages "O": specific competitive advantages of the company developed into a (local) market, difficult to imitate and easily transferred, linked to the exclusive possession of assets.

- Location advantages - Location-specific advantages "L": an external market characteristics associated with market imperfections and distortions arising from the exploitation of competitive advantages in the market, making attractive FDI there.

- Internalization - Internalization "I": The company tried to keep control of the advantages of possessing property, for which the transferred internally through his organization or subsidiaries rather than sell it or lease to a foreign company.

These elements allow us to see that the market imperfections are explaining the existence of TNC and the main reasons of business strategies to enter and invest in a market that typically are associated with this meaning: to increase and protection of benefits and sales and market protection as set out in Ball et al. (2004). These reasons can be delimited in the context of the OLI paradigm in the review of approaches to factor endowments and market failures that this framework considered. 
One of the latest investigations, who try to relate the foreign direct investments to the welfare of a nation, reveals that in the case of the countries with "poor democracy" the benefits of the FDI are not tangible for most of his people, being concentrated in just "few hands". The paper is given as an example in ECLAC Report of Foreign Direct Investment in Latin America and the Caribbean published in 2014. The paper argues that the benefits of the FDI are not equally distributed (de Groot, 2014).

Related to the economic security, in this paper we understood the economic security as the macroeconomic stability meaning politic, social and economic stability. In a constant changing world, the security is an issue to deal by the Governments in their strategies; moreover in the context of many conflicts around the world, especially after the Cold War, the security becomes even more important, as more detail offers Zavaleta (2015). In a democracy the Institution plays an important role in order to "maintain the rules of the game in the economy", for all the partners but once the corruption get upper and upper in the politics and social scale, there is less possibility that the country fulfil the economic stability and predictability, very important when we talk about foreign direct investments, therefore the corruption could threaten the national security.

Security it is indeed an abstract and relative concept. It has various interpretations and objective and subjective assessments, as well as specialized ones. In the etymological sense security means: quality insurance (from the Latin securitas) which implies security or indemnity in respect of money interests. The security is interpreted as a stable and predictable environment, where there are no fears over damage or injury to persons and their belongings. But there is also a subjective interpretation of the term when he is related to the feeling of confidence that can have a person or social group with respect to the environment in which it operates, an in the case of the economy the confidence is essential. It can be said that the security manifested in the social levels: individual, group, community, nation, state and interstate or internationally.

Security is the relative degree of assurance that any state, society, body, family or person tends to make to survive trough welfare conditions ensuring effective generational projection. The economic security has several meanings: it involves the stability of trading securities; the jurisdiction of economic relations; the regularity of the processes involved in the dynamics of the national economy; but it means also employment stability in terms of the effects on the individual in their personal economy and its commitments and aspirations.

Almost all the Constitution is the world provides key element that ensure the economic development and welfare of his population mainly by the stability and the predictability of his economy.

In the economic literature there are many studies relating the economic and social conditions to the economic security or insecurity. Rodrik (2001) in his investigations argues that in Latin America the economic security has multifaceted and has many sources that feed on each other 
(paper cited by ECLAC 2001). Here the economic security is seen as a lack of security who leads to the economic insecurity that arises from the decline in employment protection and increased volatility of household outcomes. Some of it is the result of erratic capital flows and the systemic instability generated by a "divorce between the instruments of stabilization and the real economy". Finally, an important component is the weakness of the institutions of voice and representation. He believes that macroeconomic policies have an important role in order to maintain the economic security (with regard to capital flows and the exchange rate in particular) are more conducive to the stability of the real economy and by loosening the control of financial markets over the instruments of macroeconomic policy.

Another important investigation belongs to Scheve \& Slaughter (2004). In this case, the authors took as an example the impact of the foreign direct investments in the United Kingdom and the relation with the security or the insecurity of the workers. Their findings are remarkable in the sense that they argue that as previous research focused on the role of international trade who failed to produce convincing evidence that such a link exists, they suggest that globalization increases worker insecurity, but FDI by multinational enterprises (MNE) is the key aspect of integration generating risk. FDI by MNE increases firms' elasticity of demand for labour. Moreelastic labour demands, in turn, raise the volatility of wages and employment, all of which tends to make workers feel less secure. The authors presented empirical evidence, based on the analysis of panel data from Great Britain collected from 1991 to 1999, that FDI activity in the industries in which individuals work is positively correlated with individual perceptions of economic insecurity. They found that this correlation holds in analyses accounting for individualspecific effects and a wide variety of control variables.

For many other authors the economic security is linked to the economic situation of the future generations, how they will be able to earn and save money in a society who constantly change its values, but nevertheless the macroeconomic and social policies will play an important role in the feeling this economic security or insecurity. Inglehart \& Abramson (1994) have studied the case of the perception of economic security in eight west European countries and they determined an intergenerational shift toward postmaterialist values, a time series analysis controlling for the joint effects of inflation and unemployment demonstrates that there is a statistically significant trend toward postmaterialism in all studied countries. They suggest that evidence from the 1981-83 and 1990-91 World Values Surveys indicates that this value shift occurs in any society that has experienced sufficient economic growth in recent decades so that the preadult experiences of younger birth cohorts were significantly more secure than those of older cohorts. Large intergenerational differences tend to be found in societies that have experienced rapid growth in gross national product per capita, and are negligible in societies that have had little or no growth. Accordingly, postmaterialism increased in 18 of the 20 societies on five continents for which we have comparable data over the past decade.

Authors like Cable (1995) are more concern about the global security as a whole and he ask himself who could be the enemy for the economic security, why this should and may be threaten? 
The author take issue with the proponents of the idea of "geo-economics" a model based on a confrontational model of international economic activity that has gain some currency in the US, Japan and the EU. Examining the arguments that have been put forward on the ground of the economic security for protecting domestic supplies, technologies and markets, he demonstrates that contemporary global condition often calls for an cooperative rather than confrontational pursuits of an economic security that in the opinion of the author is a shared condition rather than a goal of individual states. As mentioned earlier the concept of the economic security is very large and we can understood it through many dimensions: employment, wages, economic purchase power, security, wars (Carter \& Paul 2015) but as far as we know there is no paper analysing the impact of the FDI flows in Latin American countries through an economic security issue as we do in the present article.

In the economy the confidence and predictability of an economy it is very important when we talking about the FDI. The state of low it supposes to protect not just the population of criminal actions and corruption but his economy as well. In this paper we will find that in the case of Latin American countries there is a strong negative correlation between FDI flows and the corruption index.

\section{STYLIZED FACTS. DESCRIPTIVE STATISTICS AND ASPECTS OF FDI IN LATIN AMERICA}

FDI inflows in Latin America and the Caribbean reached over 188.101 million dollars in 2013, 6\% more than the previous year as ECLAC figures present. After a rapid rises in 2007 and 2008 and a significant drop about 40\% in 2009, the FDI in 2010 and 2001 began to recover. FDI flows into the region have remained stable. Annual growth was modest in 2012 and 2013, especially considering that FDI is measured in nominal terms. As we said before in this paper we take into consideration the first ten economies of Latin America: Brazil, Mexico, Chile, Colombia, Argentina, Panama, Peru, Uruguay, Venezuela and Costa Rica.

The economic growth in the region and the high international demand for export commodities were the responsible for the rise of the FDI in the region. The region's GDP growth decreased to $2.5 \%$ in 2013 (ECLAC, 2014b), the lowest rate since the global financial crisis made itself felt in 2009.

The largest recipient of FDI inflows in Latin America and the Caribbean was Brazil, with more than 64.000 billion dollars in 2013 and Mexico, the region's second largest economy, with 38.200 billion dollars, a record figure thanks to the acquisition of Grupo Modelo (16.000 million dollars). Mexico was the country where the FDI increase more in 2013 comparing to the previous year. Brazil received less FDI than in 2012 with about 1 billion dollars, Argentina 3 billion less and Chile 8 billion less that in 2012. Peru, Venezuela, Colombia and Costa Rica received more FDI in 2013 than in 2012 with a slight difference with a difference between 300 million to 1.6 billion dollars. 
Going forward with the description of the FDI we notice that taking into account the total amounts of FDI in the ten economies that we are centred in the present paper, only Argentina and Venezuela attract less foreign investment in 2013 compared with the initial year, 2000. Brazil and Mexico multiplied by 2 the FDI of 2000 (in absolute terms being the highest of the region), Chile multiplied by 4, Colombia and Costa Rica by 5, Panama by 7 and Peru and Uruguay by 11 (from 270 million dollars in 2000 up to 2.8 billion dollars in 2013).

These facts give us a clue about the economic development of the studied countries just by looking the FDI flows: we can easily guess that Argentina and Venezuela had some important economic and political instability and if we those economic figures of these two countries we see that we have right in our supposition.

The second block of countries who multiplied the FDI flows by 4 and 5 were countries with a rapid economic growth, Chile, Colombia and Costa Rica, countries with and macroeconomic stability and less political turbulence. The most relevant cases maybe the case of Uruguay and especially of Peru who multiplied they flow by 11 in 14 years of study. If Uruguay multiplied his Total Gross Domestic Product (GDP) by 2.5, Peru did it more than 4 times from 51 billion dollars to more than 200 billion dollars. In both countries the percentage of FDI over their GDP grow from 1 to $5 \%$ wich in economics is a very high percentage.

The earlier cases of Argentina and Venezuela, the FDI flows at the beginning of the period represented $4-5 \%$ of their total GDP in 2013 it barely represent 0.5 to $1.3 \%$ being a significant drop.

But not in all of the studied countries the FDI was concentred in a determinate sector: in countries like Venezuela, Peru, Chile and Colombia the FDI were concentrated in the natural resource sector, in the industrial sector, in Argentina and especially Mexico in the manufactured sector and Brazil, Costa Rica, Uruguay and especially Panama (98\%) was concentrated in the service sector. The case of Panama is mainly because of the panama Chanel operations (taxes paid by the ships and investments made to improve and enlarge it).

The main investor in Latin America is the United States in Argentina, Brazil, Chile, Costa Rica, Mexico and in Panama, followed by Spain in Venezuela and Peru. Spain and the Nederland's are the second investors in Brazil, Chile and Mexico.

The importance of the FDI in Latin America relies on the economic and social impact that they have, or they supposed to have. The question that we made is in which extent the corruption, the economic stability and a functional state of low could have an impact on the national economy in the context of the above mentioned economic security. The next section will give us a clue. 


\section{ISSUES RELATED TO THE ECONOMIC SECURITY IN LATIN AMERICA}

In the '80s, Latin American countries began a rapid process of democratization so that in the '90s, all countries of the region, except Cuba, had freely elected governments. The traditional military dictatorship with left or right ideology, populist or conservative make place to new governments that assumed the task of renewing and strengthening political institutions in each country.

During this time the main concern of the governments were to prevailed objectives of economic consolidation and reforms, but the public opinion and governments paid little attention to the corruption problem. In the climate of more and more liberty and economic deceptions the issue of corruption began to have a more important relevance.

In the interventionism, subjecting the economy to the politics field inevitably will create situations in which representatives of public authority will act as his own wish, thereby will increased corruption. A limited government, under clear and accurate laws, will cause less chance for corruption acts. (Sabino, 1999).

In order to demonstrate that the corruption did play an important role on FDI attraction on Latin American countries we plot the sum of the FDI in the ten considered economies against their corruption level using figures from the official reports of CPI (Corruption Perception Index) made by Transparency International ${ }^{1}$ each year:

Graph 1. FDI \% of the GPD and the relation with the corruption index 2000-2014

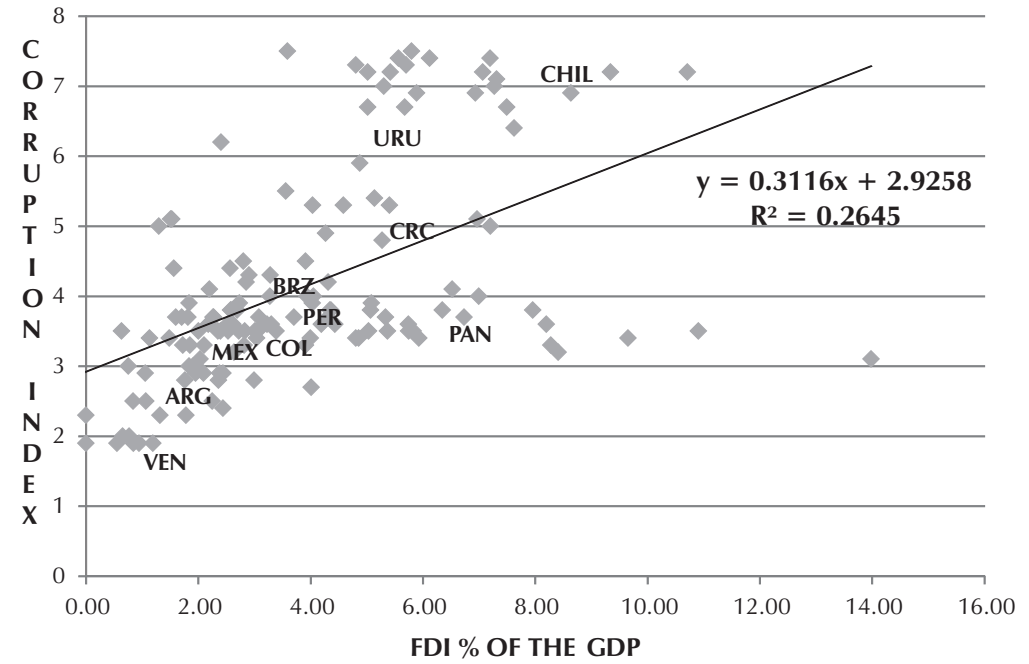

Source: Own elaboration based on CEPALSTAT figures

1. Transparency International gives at each country set of point in different areas where the corruption can exist, the score is between 0 and 10, 0 being perceived as highly corrupt and 10 no corruption was detected. 
We can easily see that the relation between the FDI flows and the corruption index is clearly positive and concluding as $r^{2}$ is 0.26 . The previous graph shows that generally as much as a country is less corrupt more FDI flows received. We have to mention that the FDI flows are computed as the percentage of GDP, because is more relevant that the nominal values, as big economies (Brazil and Mexico) attract far more FDI than small ones (Costa Rica and Uruguay). In the graph the point cloud surrounding the name of the country represents the average values of the 14 years studied.

If we take the case of Venezuela we can easily observe that the corruption index is very low, actually the lowest of the studied countries and it corresponds the lowest FDI flows. For instance in the year 2000 Venezuela received FDI representing more than $4 \%$ of his GDP, the corruption index was 2.7, but until 2013 the political and economic situation worse and the corruption index is 1.9 and the FDI flows drops dramatically down to $0.95 \%$ of the GDP. This is the most extreme case of the Latin America economies that shows without any kind of doubt that the corruption index is directly related to the FDI flow, we admit that is not the only factor. In the case of Venezuela the FDI reduce his flow 4 times in the same manner as the corruption perception did.

To point out the most successful example, we take the case of Uruguay, if at the beginning of the above mentions period, the corruption level was 5 the FDI flows represented just $1.3 \%$ of his GDP but as the economic reforms were successfully implemented, Uruguay became the less corrupt country in Latin America, being the first one or the second one during this period, just after or behind Chile, rising his score up to 7.3 in 2013 the same score as Chile. In this last year Uruguay was able to attract FDI representing more than $5.2 \%$ of his GDP (a rise of almost 4\%).

Panama is a very special case: due to the Panama Channel investments, the FDI flow rise considerably in this country but the corruption index remains much or less the same around $3.4-3.6$.

Furthermore in the case of main Latin American economies Brazil and Mexico are in line with the prediction in the sense that the FDI flows did not change dramatically as percentage of GDP as well as he did not the corruption index: he improve slightly from 3.3 to 3.5 in Mexico and from 3.9 to 4.3 in the case of Brazil. Moreover the "rules" applies in the case of Costa Rica and Colombia who did improve their FDI attraction from 2.5 to $5.4 \%$ (Costa Rica) and from 2.6 to $4.6 \%$ of their GDP in the mentioned period and in the same time improve their ranking being a less corrupt country - from 4.4 to 5.4 -Costa Rica and from 3.2 to 3.7 as Transparency international informs.

As we understand the economic security as a macroeconomic stability in the case of failure could be considered a national security problem. As we mentioned before the FDI flows in a country did not necessary led to an improved the macroeconomic stability, they are many other 
factors to take into consideration, but we refer here just to the investments case. From the above analysis we can say that the corruption is a very important variable to take into consideration when we talk about the FDI flows, and as we discuss in the literature review part, the great majority of the economists are agreeing that FDI flows are necessary to countries who doesn't have sufficient capital to make any kind of investments. As a country presents high levels of corruption the rule in Latin America countries, is that less FDI flows receives, the investment climate is less favourable for doing business.

The discussion about whether the FDI flow in an economy plays an important role in the sense that the population perceive FDI as something beneficial here the opinions are quite diverse. In our particular case, of the Latin American countries we consider appropriate to measure the relation of the FDI flows to the GINI coefficient of each country.

The GINI coefficient measures the inequality among values of a frequency distribution (for example, levels of income). A GINI coefficient of zero expresses perfect equality, where all values are the same (for example, where everyone has the same income -that doesn't occurred in real world). A GINI coefficient of 1 (or 100\%) expresses maximal inequality among values (for example, where only one person has all the income or consumption, and all others have none). So as much as the GINI coefficient of a country is close to 1 the larger is the difference between the incomes of his population. We decide for the GINI coefficient because we wanted to see if the income distribution in Latin American countries was indeed influenced by the huge FDI flows that the region attracts in the last 15 years.

The GINI coefficient is one of the instruments to measure the differences on income distribution in an economy (Cruz, 2004) $)^{2}$. As mentioned before the FDI could help an economy in need of fresh capital but if the FDI are concentrated in non-productive sectors or non-productive investments -which mean that it does not create many jobs in the economy- the population will not perceive the FDI as something good, will occur exactly the contrary -as ware the cases of Venezuela, Bolivia and Argentina- where Spanish, American and Canadian companies were forced to give up to some investment due to political and social turmoil. This kind of political and legal issues could threat the economic stability in the context of economic security being one of the compound elements of national security.

Next graph 2 expresses the relation that we found between the FDI flows as a percentage of the GDP and the GINI coefficient of the studies countries:

2. As discussed Cruz (2013), you can analyze income distribution through other indicators that relate exclusively income decile, however, the most common is the Gini coefficient. 
Graph 2. FDI \% of the GPD and the relation with the GINI coefficient 2000-2014

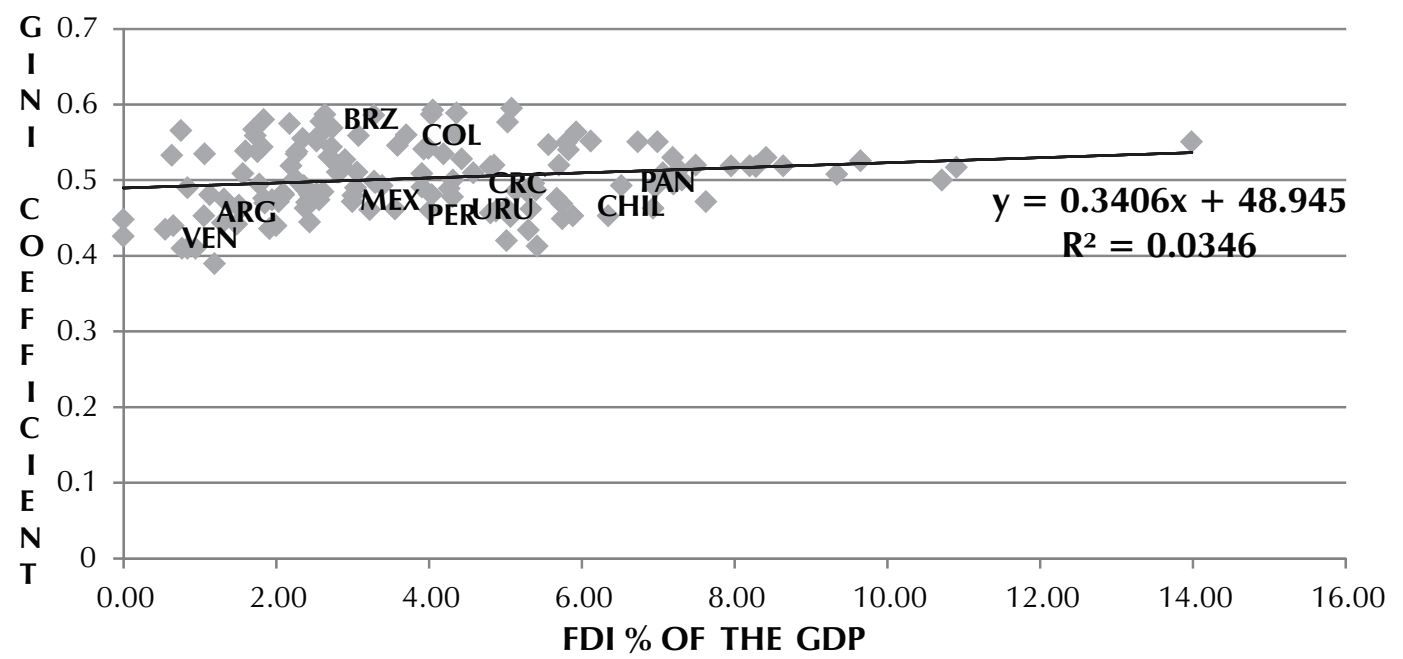

Source: Own elaboration based on CEPALSTAT figures.

The GINI coefficient in Latin American countries that we take into consideration for the paper, presents values between 0.39 (Venezuela) to 0.59 (Brazil). Once again, as expected the relation between the FDI flows and the income distribution expressed by the GINI coefficient is positive and significant, even if the risk is less that in the previous case. The interpretation of the clues given by the graph 2 lead to the conclusion that as much as FDI flows a country receives (we refer here exclusively to the analysed ones) the higher is the GINI coefficient that country presents. This coefficient tells us that the difference between the riches and pores had increased even if the majority of the countries did experiment an increased flow of FDI.

So we can easily see that the investments in Latin American countries did not produce as many jobs as expected or another explanation could be that the investments made in service sector create jobs very well paid, above the national average and those made in the manufacture (the majority in Latin America) create less jobs or with lower salaries. In this sense Venezuela and Argentina are eloquent: in Venezuela as we seen before due to the political and social instability the FDI flows drops dramatically and in the same time the GINI coefficient did to from 46 to 41, and in the Argentinean case, even more significant from 51 to 44. Moreover in the opposite case Costa Rica who doubled the percentage of FDI flows in terms of GDP, as expected did increase his GINI coefficient from 47 to 49.

Generally in Latin America and the Caribbean countries the GINI coefficient presented a slow reduction during the analysed period. This elements are part of the capitalism and globalisation, but the critics of globalization today call for greater equality, contending that the increased international flow of factors of production has benefited the rich more than the poor (Stiglitz, 2002; Soros 2002). 
To be more precise with the presented analyses we made an econometric estimation run with Eviews, an econometric program. EViews can be used for general statistical analysis and econometric analyses, such as cross-section ${ }^{3}$ and panel data ${ }^{4}$ analysis and time series estimation and forecasting. In this paper we made a cross -section estimations using the method of Least Squares ${ }^{5}$ where the dependent variable is total FDI in each country between 2000 and 2013, the main results are presented below:

Table 1. Dependent variable in total FDI. 2000-2013

\begin{tabular}{|c|c|c|c|c|}
\hline \multicolumn{5}{|c|}{ Dependent Variable: TOTFDI } \\
\hline \multicolumn{5}{|l|}{ Method: Least Squares } \\
\hline \multicolumn{5}{|l|}{ Sample: 1140} \\
\hline \multicolumn{5}{|c|}{ Included observations:140 } \\
\hline Variable & Coefficient & Std. Error & t-Statistic & Prob. \\
\hline $\mathrm{C}$ & 24169.12 & 5709.142 & 4.233406 & 0.0000 \\
\hline TOTGDP & 0.024083 & 0.000962 & 25.03212 & 0.0000 \\
\hline GDPCAP & 0.286158 & 0.156430 & 1.829297 & 0.0696 \\
\hline GINI & 365.7919 & 107.2690 & 3.410044 & 0.0009 \\
\hline CORRUPTION & 1254.513 & 288.1856 & 4.353141 & 0.0000 \\
\hline R-squared & 0.880673 & \multicolumn{2}{|c|}{ Mean dependent var } & 9618.250 \\
\hline Adjusted R-squared & 0.877138 & \multicolumn{2}{|c|}{ S.D. dependent var } & 12842.72 \\
\hline S.E. of regression & 4501.594 & \multicolumn{2}{|c|}{ Akaike info criterion } & 19.69731 \\
\hline Sum squared resid & $2.74 \mathrm{E}+09$ & \multicolumn{2}{|c|}{ Schwarz criterion } & 19.80237 \\
\hline Log likelihood & 1373.812 & \multicolumn{2}{|c|}{ Hannan-Quinn criter. } & 19.74000 \\
\hline F-statistic & 249.0869 & \multicolumn{2}{|c|}{ Durbin-Watson stat } & 1.223683 \\
\hline
\end{tabular}

Source: Own elaboration.

3. Cross-sectional data or a cross section of a study population, in statistics and econometrics is a type data collected by observing many subjects (such as individuals, firms, countries, or regions) at the same point of time, or without regard to differences in time. Analysis of cross-sectional data usually consists of comparing the differences among the subjects.

4. In statistics and econometrics, the term panel data refers to multi-dimensional data frequently involving measurements over time. Panel data contain observations of multiple phenomena obtained over multiple time periods for the same firms or individuals.

5. The method of least squares is a standard approach to the approximate solution of overdetermined systems, i.e., sets of equations in which there are more equations than unknowns. "Least squares" means that the overall solution minimizes the sum of the squares of the errors made in the results of every single equation. The method is divided into linear and nonlinear last squares. 
First of all we observe that the estimation is positive and statistically significant as the $r^{2}$ is 0.88 , wich basically means that the $88 \%$ of the FDI flows in Latin American countries (TOTFDI) considered for the study is explained by the four variables considered: total GDP (TOTGDP), per capita GDP (GDPCAP), GINI coefficient (GINI) and corruption index (CORRUPTION). The estimation proves that the tot GDP and per capita GDP does not have an important influence in order to explain the FDI flows as the coefficient is very low $(0.002$ and 0.28 respectively). But this is not the case of the next two variables who explains much of the foreign investments in the region, and especially the corruption variable that has the higher coefficient (1254) which is in line with what we argue in the explanations of the graph 1 and in the same time it conforms the hypothesis: the FDI is important in order to maintain an macroeconomic stability but is not the only condition, the state of low -the level of corruption- plays an important role in how the benefits of the FDI could be understood and felt by the Latin American societies.

The corruption without any kind of doubt is a major problem that Latin American economies suffer. The GINI coefficient was influenced but not that much as the corruption did, and once again is in line with the predictions made on the Graph no.2. We show that the GINI coefficient did reduce his values in most of the cases, but increased in the economies who less FDI received. This does not mean that the condition to have a better GINI coefficient is having less investment, it means that the ideal situation is that where the FDI is creating as much as many well pays jobs as possible, it create social welfare, but they are many reasons that in Latin America is not the case: the corruption and a weak state of low is one of the explanation.

\section{CONCLUSION}

The FDI as many economist considered is a very important element to be considered in order to explain the possibility of an economic growth if that economy doesn't have much capital to do it by public funds, or doesn't want to for not having sufficient experience in a specific field.

Now if the foreign investments produce benefits that is a controversial issue as they are cases where it did generate benefits for the economy and for the society, mainly in less corrupt countries where the stat of low is a fact; but many studies shown that the benefits are quite uneven in less developed countries, with a weak state of low or very corrupt countries who could easily jeopardise the macroeconomic stability and therefore transforming it into a nation security problem. We understand economic security as macroeconomic stability who could be given by the macroeconomic policies but as well at least in part by the foreign direct investment, that could generate incredible welfare for the whole society if the country has a functional state of law and low levels of corruption. In our paper in the sample of Latin American economies we saw that generally the FDI flows were very high and correlated to the corruption index as Transparency Internationals present in their annual report. Using simple correlation graphic 
representations we found that the corruption did play an important role in order to explain the amount of FDI, the cases of Venezuela and Argentina in opposition with the cases of Chile and Uruguay. Moreover the econometric results, obtain by Eviews econometrics with the Least Squares Method, are in line with the predictions made before, as the estimation is positive and statistically significant.

Using this econometric approach, we correlate the foreign direct investments with the GINI coefficient and the corruption index and the result whore as expected in the sense that the higher the FDI flow were the higher is the income differences in the economy explain partly by the uneven benefits of the FDI in countries with a weak state of low and a high level of corruption, who eventually lead to an important macroeconomic imbalance and could jeopardise the economic stability of a country and his economic security, for instance the nowadays case of Venezuela.

There is no doubt that the corruption and a weak state of low has a dramatic influence in the economy, as the state is the 'game ruler' and this connection between economic welfare and corruption it should be considered in most of the cases an economic security issue and therefore an national security problem to.

\section{REFERENCES}

Balasubramanyan V., Salisu, M., \& Sapsford, D. (1996). Foreign Direct Investment and Growth in EP and IS Countries. Economic Journal. (106), 96-105.

Ball, D. et al. (2004). International Business, the challenge of global competition. Mc. Graw Hill: New York.

Cable, V. (1995). What is international economic security? Royal Institute of International Affairs, $71(2), 305-324$

Carter, B., \& Paul, P. (2015). Why do states build walls? Political Economy, Security, and Border Stability. New Jersey: Princeton University.

Caves, Richard, (1999). Multinational enterprise and economic analysis. Nueva York: Cambridge University Press.

Cruz, J. (2013). La distribución del Ingreso y los modelos de desarrollo en México. México D.F.: Instituto de Investigaciones Económicas.

(2015). Income Distribution and Poverty as Obstaclesto the Recovery of the European Union. Revista De Relaciones Internacionales, Estrategia y Seguridad, 10(1), 135-158. 
Dunning, J. (1988). The eclectic paradigm of international production: a restatement and some possible extensions. Journal of International Business Studies, 19, 1-32.

Eiteman, D., Stonehill, A. \& Moffett, M. (2007). Multinational Business Finance, Nueva Jersey: Pearson.

Findlay, R. (1970). Trade and specialization. Harmondsworth: Penguin Books.

Groot de, O. (2014). Foreign direct investments and welfare. Production Development series. 6-19

Hecksher E., Ohlin B. \& Chamberlain E. (1933). International trade in the presence of product differentiation, economies of scale and monopolistic competition: A ChamberlinHeckscher-Ohlin approach. Journal of International Economics, 11(3), 305-340.

Inglehart R. \& Abramson P. (1994). Economic security and value changes. American Political Science Review, 88(2), 20-32

Johanson J. \& Valhne, J. (1990). The Mechanism of Internationalization. International Marketing Review, (7), 11-24.

Krugman, P. \& Obstfeld, M. (2002). Economía internacional; teoría y política. Madrid: McGraw Hill.

Posner, M. (1961). International trade and technical change. Oxford Economic Papers, 13, 323341.

Ricardo, D. (1817, 1996). Principles of Political Economy and Taxation, Londres: John Murray Edition.

Rodrik, D. (2001). ¿Por qué hay tanta inseguridad económica en América Latina? Revista de la Cepal, 73.

Kojima, K. (1978). Direct Foreign Investment: A Japanese Model of Multinational Business operations, London: Croom Helm Editions.

Kravis, I. (1956). Availability and other influences on the commodity composition of trade. Journal of Political Economy, 64(2), 143-155.

Porter, M. (1987). The competitive advantage of nations. New York: The Free Press Edition.

Sabino, C. (1999). Democracia y corrupción en América Latina. Revista del CLAD, 40-41. 
Scheve, K. \& Slaughter, J. (2004). Economic insecurity and the globalisation of production. American Journal of Political Science, 48(4), 62-67.

Shoham, A. (1998). Export performance: A conceptualization and empirical assessment. Journal of international marketing, 6(3), 59-81.

Solow, R. (1957). Technical Change and the Aggregate Production Function. Review of Economics and Statistics, 39(3), 312-320.

Soros, G. (2002). George Soros on Globalization. New York: Public Affairs Edition, Perseus Books Group.

Stiglitz, J. (2003). Globalization and Its Discontents, New York: W. W. Norton Edition.

Zavaleta, S. (2015). El Concepto de Seguridad Humana en la Relaciones Internacionales. Revista de Relaciones Internacionales, Estrategia y Seguridad, 10(1), 65-87. 